\title{
UPAYA MENINGKATKAN KEMAMPUAN MENGAJAR MAHASISWA JURUSAN PENDIDIKAN ISLAM ANAK USIA DINI (PIAUD) IAIN SALATIGA
}

\author{
Oleh: \\ Siti Asdiqoh \\ Dosen Jurusan PIAUD IAIN Salatiga
}

\begin{abstract}
ABSTRAK
Guru merupakan salah satu unsur dalam proses belajar mengajar yang harus berperan aktif dan menempatkan kedudukannya sebagai tugas profesional sesuai dengan tuntutan masyarakat. Oleh karena itu, untuk dapat melaksanakan tugas dan tanggung jawabnya, guru memerlukan syarat-syarat tertentu yang dapat diklasifikasikan menjadi persyaratan administratif, persyaratan teknis, dan persyaratan kepribadian. Guru dituntut adanya kualifikasi kemampuan yang memadai. Secara garis besar ada tiga tingkatan kualifikasi profesional guru sebagai tenaga profesional pendidikan yaitu capable personal, guru sebagai inovator, dan guru sebagai developer. Sebagai upaya meningkatkan kemampuan mengajar mahasiswa PIAUD IAIN Salatiga, kegiatan microteaching sebagai latihan mengajar dilaksanakan oleh mahasiswa dan diharapkan akan tumbuh suatu kebiasaan tingkah laku yang baik dalam diri mahasiswa calon guru. Melalui microteaching, mahasiswa juga belajar untuk menguasai kompetensi profesional guru yang meliputi kompetensi paedagogik, profesional, sosial, dan kepribadian.
\end{abstract}

Kata Kunci: Kemampuan Mengajar, Kualifikasi Profesional, Kompetensi Guru

\section{Persiapan Calon Guru}

\section{Persyaratan Calon Guru}

Guru adalah salah satu unsur dalam proses belajar mengajar harus berperan aktif dan menempatkan kedudukannya sebagai tugas profesional sesuai dengan tuntutan masyarakat. Oleh karena itu, untuk dapat melaksanakan tugas dan tanggung jawabnya, guru memerlukan syarat-syarat tertentu. Syarat-syarat inilah yang membedakan antara guru dengan profesi lain. 
Dalam Standar Nasional Pendidikan (SNP) pasal 28 dikemukakan bahwa: "Pendidik harus memiliki kualifikasi akademik dan kompetensi sebagai agen pembelajaran, sehat jasmani dan rohani, serta memiliki kemampuan untuk mewujudkan tujuan pendidikan nasional". ${ }^{1}$ Adapun syarat-syarat lain bagi guru dapat diklasifikasikan sebagai berikut:

a. Persyaratan administratif

Persyaratan ini telah ditentukan sesuai dengan kebijakan yang ada misalnya: soal kewarganegaraan, berkelakuan baik, ijazah yang diperlukan.

b. Persyaratan teknis

Persyaratan ini khusus mengenai keterampilan sebagai seorang guru misalnya, mampu mengajar, mendesain program pengajaran, memiliki motivasi mengajar, dan lain-lain.

c. Persyaratan kepribadian

Persyaratan ini berkaitan dengan kesehatan jasmani dan rohani. Guru harus juga mematuhi norma dan nilai yang berlaku serta memiliki semangat membangun.

Sesuai dengan tugas dan profesinya, maka guru dipersyaratkan mempunyai beberapa kemampuan antara lain: ${ }^{2}$

a. Memiliki kemampuan profesional

b. Memiliki kapasitas intelektual

c. Memiliki sifat edukasi sosial

1 Mulyasa, E. 2007. Standar Kompetensi dan Sertifikasi Guru. Bandung: Remaja Rosdakarya. hlm. 53.

2 Sardiman A.M., 1990. Interaksi dan Motivasi Belajar Mengajar. Jakarta: Rajawali. hlm. 125. 
Ketiga syarat kemampuan itu diharapkan telah dimiliki oleh setiap guru, sehingga mampu memenuhi fungsinya sebagai pendidik, karena guru merupakan jabatan atau profesi yang memerlukan keahlian khusus sebagai guru. Pekerjaan ini tidak bisa dilakukan oleh orang yang tidak memiliki keahlian untuk melakukan kegiatan atau pekerjaan sebagai guru. Untuk menjadi guru diperlukan syarat-syarat khusus, apalagi sebagai guru yang profesional yang harus menguasai betul seluk beluk pendidikan dan pengajaran dengan berbagai ilmu pengetahuan.

Ibnu Sina mensyaratkan, guru harus berpikiran maju, beragama, berakhlak, berwibawa, berpendirian tetap, dan menghargai murid. ${ }^{3}$ Sutari Barnadib mensyaratkan, seorang guru harus mempunyai kesenangan bekerja sama dengan orang lain dan untuk kepentingan orang lain, sehat jasmani dan rohani, betul-betul berbakat, berkepribadian baik dan kuat, disenangi dan disegani oleh murid, emosinya stabil, tidak lekas marah dan tidak penakut, tenang, objektif dan bijaksana, susila dan tingkah lakunya jujur dan adil.

Sebagai tenaga profesional, guru harus memenuhi sejumlah persyaratan. Persyaratan tersebut adalah:

a. Memiliki kualifikasi akademik

b. Memiliki kompetensi

c. Memiliki sertifikat pendidik

d. Sehat jasmani dan rohani

e. Memiliki kemampuan untuk mewujudkan tujuan pendidikan nasional

Kualifikasi akademik adalah ijazah jenjang pendidikan akademik yang harus dimiliki oleh guru sesuai dengan jenis, jenjang, dan satuan pendidikan formal di tempat penugasan. Kualifikasi akademik ini ditunjukkan dengan

\footnotetext{
${ }^{3}$ Abidin Ibnu Rusn, 1998. hlm. 65.
} 
ijazah yang merefleksikan kemampuan yang dipersyaratkan bagi guru untuk melaksanakan tugas sebagai pendidik pada jenjang, jenis, dan satuan pendidikan atau mata pelajaran yang diajarkannya sesuai Standar Nasional Pendidikan. ${ }^{4}$

Pada prinsipnya, untuk menjalankan pembelajaran dengan baik, guru harus membekali diri dengan tiga kemampuan dasar yaitu: didactic, coaching, dan socratic.

a. Didactic, berkenaan dengan kemampuan guru dalam menyampaikan sesuatu atau dikenal dengan ceramah. Kemampuan ini dapat didukung dengan adanya buku teks, alat peraga, lembar kerja siswa, dan media pembelajaran.

b. Coaching, berkenaan dengan kemampuan guru dalam memberikan kesempatan kepada siswa untuk berlatih dan mempraktikkan keterampilannya. Praktik yang dilakukan siswa sebaiknya segera diberi umpan balik untuk melihat ketercapaian tujuan serta perbaikan kelemahan.

c. Socratic, berkenaan dengan kemampuan guru dalam menggunakan pertanyaan, pengarah untuk membantu siswa memperluas pemahaman terhadap materi yang dipelajari, serta membantu siswa yang belum menguasai materi.

Selain tiga kemampuan di atas, seorang guru harus memiliki karakteristik sebagai berikut: ${ }^{5}$

a. Memiliki kompetensi pendidikan meliputi pengetahuan, pamahaman nilai dan sikap, serta kemampuan.

${ }^{4}$ Farida, 2008. Hlm. 15.

5 Jamil S., 2013. hlm. 69. 
b. Memahami peran seorang guru, yaitu mendidik, membimbing, dan melatih.

c. Memiliki kepribadian yang luhur (akhlakul karimah).

d. Dapat membantu siswa dan menimbulkan sikap positif.

e. Responsif terhadap perubahan yang terjadi.

Menurut Hamalik (2003) pekerjaan guru adalah pekerjaan profesional maka dengan menjadi guru harus memenuhi persyaratan yang berat. Beberapa diantaranya ialah:

a. Harus memiliki bakat menjadi guru

b. Harus memiliki keahlian sebagai guru

c. Memiliki kepribadian yang baik dan terintegrasi

d. Memiliki mental yang sehat

e. Berbadan sehat

f. Memiliki pengalaman dan pengetahuan yang luas

g. Guru adalah seorang warga negara yang baik

Menjadi guru di era global pasti tidaklah mudah. Ada berbagai persyaratan yang harus dipenuhi agar dia dapat berkembang menjadi guru yang profesional. Untuk melihat apakah seorang guru dikatakan profesional atau tidak, dapat dilihat dari dua perspektif. Pertama, dilihat dari tingkat pendidikan minimal dari latar belakang pendidikan untuk jenjang sekolah tempat menjadi guru. Kedua, penguasaan guru terhadap materi ajar, mengelola proses pembelajaran, mengelola siswa, melakukan tugas-tugas bimbingan, dan lain-lain.

\section{Microteaching Sebagai Latihan Mengajar}

Mengajar merupakan kegiatan yang sangat kompleks yang mengandung banyak tindakan, mencakup teknik penyampaian materi, penggunaan metode, penggunaan media, pengelolaan kelas, pemberian penilaian, 
pemberian motivasi, dan sebagainya. Kompleksitas perbuatan mengajar tersebut mengalami kesulitan untuk menerapkan semua komponen dalam perbuatan mengajar secara integratif. Oleh karena itu, dalam rangka penguasaan komponen mengajar, calon guru perlu latihan.

Latihan mengajar merupakan kegiatan yang sangat vital bagi setiap calon guru. Penguasaan teori mengajar tidak cukup sebagai bekal untuk menjadi guru yang profesional tanpa melalui tahapan latihan mengajar. Menurut para guru pamong, para mahasiswa praktikan biasanya kurang memiliki kesiapan terutama dalam segi keterampilan dan sikap mental sehingga tidak berhasil menampakkan performennya secara mantap dan meyakinkan.

Dalam hal ini microteaching merupakan usaha yang ditempuh dalam rangka meningkatkan kemampuan calon guru dalam mengemban profesi keguruannya. Pelaksanaan pembelajaran microteaching ini pada prinsipnya merupakan realisasi pola-pola pembelajaran yang sesungguhnya yang didesain dalam bentuk micro. Setiap calon guru membuat persiapan mengajar yang kemudian dilaksanakan dalam proses pembelajaran bersama teman sejawat. Dengan demikian, proses itu dapat diatur menurut kebutuhan serta disesuaikan dengan tujuan yang akan dicapai. Oleh karena itu, microteaching sering diartikan sebagai mengajar dalam bentuk mini.

Microteaching memiliki ciri-ciri pokok yaitu:

a. Dilaksanakan dalam kelas laboratori

b. Siswa 5-10 orang untuk kelas teman sejawat.

c. Waktu sekitar 10-20 menit

d. Bahan terbatas

e. Keterampilan yang dilatihkan meliputi semua teaching skill dan terintegrasi, namun dalam porsi yang terbatas dan dapat dilatihkan secara terpisah tiap-tiap komponen. 
f. Dibutuhkan alat-alat laboratorium agar dapat diperoleh suatu feed back yang objektif.

Dalam microteaching ini diutamakan adanya diagnosa terhadap kelebihan dan kekurangan mahasiswa dalam praktik mengajar. Pada saat itu calon guru dapat mengetahui kekurangan dan kelebihannya sehingga semaksimal mungkin kekurangan-kekurangan yang ada dapat diperbaiki.

Latihan demi latihan harus diprogramkan secara sistematis dan konsisten. Dengan demikian diharapkan akan tumbuh suatu kebiasaan tingkah laku yang baik dalam diri mahasiswa calon guru. Oleh karena itu, diperlukan latihan secara kontinu melalui program microteaching.

\section{Keterampilan Dasar Mengajar}

Keterampilan mengajar merupakan kompetensi profesional yang cukup kompleks sebagai integrasi dari berbagai kompetensi guru secara utuh dan menyeluruh. Mengajar merupakan usaha yang sangat kompleks karena guru yang memulai dan mengakhiri setiap interaksi belajar mengajar. Oleh karena itu, dalam melaksanakan interaksi belajar mengajar perlu adanya beberapa keterampilan mengajar.

Beberapa keterampilan mengajar dapat dibagi dalam tiga klasifikasi yaitu yang berkaitan dengan aspek materi, aspek kesiapan, dan keterampilan operasional.

\section{a. Aspek Materi}

Pada bagian ini guru harus mempunyai keterampilan untuk menarik atau membawa perhatian siswa pada materi pelajaran yang baru dan urutan atau sistematika dalam penyampaian bahan. Guru yang kurang menguasai bahan dan tidak berwibawa dapat menjadi penyebab tidak terciptanya kontak yang baik antara guru dengan siswa. Sedapat mungkin hendaknya diusahakan agar tercipta interaksi yang aktif dari 
kedua belah pihak dalam membahas bahan pelajaran. Guru hendaknya mampu membangkitkan dan mengembangkan keaktifan siswa dalam belajar.

b. Aspek kesiapan

Aspek kesiapan dalam mengajar adalah segala sesuatu yang terlebih dahulu ada untuk dipersiapkan sebelum memulai proses pembelajaran. Hal-hal yang perlu disiapkan mencakup bahan pengajaran, media pengajaran, dan peralatan pengajaran. ${ }^{6}$ Apabila guru mengajar tanpa persiapan yang lengkap dan matang, maka proses pembelajaran akan tanpa arah dan sulit mencapai tujuan pembelajaran yang sebenarnya. Persiapan rencana pembelajaran yang baik akan mudah tercapai tujuan pembelajaran termasuk persiapan mental yang bagus.

c. Keterampilan Operasional

Pada keterampilan ketiga ini adalah keterampilan yang meliputi:

1) Membuka pelajaran dan menutup pelajaran

Yang dimaksud membuka pelajaran adalah kemampuan guru dalam memulai interaksi belajar mengajar. Menutup pelajaran adalah kegiatan mengakhiri pelajaran. Membuka dan menutup pelajaran yang dilakukan secara profesional akan memberikan pengaruh positif terhadap kegiatan antara lain:

a) Membangkitkan motivasi peserta didik

b) Peserta didik memiliki kejelasan mengenai tugas-tugas yang harus dikerjakan dan langkah-langkah yang harus dilakukan untuk menyelesaikan tugas.

${ }^{6}$ Suwardi. 2007. Manajemen Pembelajaran, Mencipta Guru Kreatif dan Berkompetensi. Salatiga: STAIN Salatiga Press. hlm. 124. 
c) Peserta didik memahami hubungan antara bahan-bahan atau pengalaman yang telah dimilikinya dengan hal-hal baru yang akan dipelajari.

Membuka pelajaran merupakan suatu kegiatan yang dilakukan guru untuk menciptakan kesiapan mental dan menarik perhatian peserta didik secara optimal agar mereka memusatkan diri sepenuhnya pada pelajaran yang akan disajikan. Kegiatan membuka pelajaran meliputi:

a) Mengucapkan salam pembuka

b) Memimpin doa

c) Mengabsen siswa

d) Menyampaikan informasi

Agar kegiatan membuka pelajaran berhasil guna, maka dapat dilakukan upaya-upaya sebagai berikut:

a) Menghubungkan materi yang telah dipelajari dengan materi yang akan disajikan

b) Menyampaikan tujuan yang akan dicapai dan garis besar materi yang akan dipelajari

c) Menyampaikan langkah-langkah kegiatan pembelajaran dan tugas yang harus diselesaikan untuk mencapai tujuan yang telah dirumuskan

d) Mendayagunakan media dan sumber belajar yang sesuai dengan materi yang disajikan

e) Mengajukan pertanyaan, baik untuk mengetahui pemahaman peserta didik terhadap pelajaran yang telah lalu maupun untuk 
menjajagi kemampuan awal berkaitan dengan bahan yang akan dipelajari. $^{7}$

Menutup pelajaran dilakukan pada akhir setiap pelajaran. Sebagaimana membuka pelajaran, menutup pelajaran pun perlu dilakukan secara profesional, untuk mendapatkan hasil yang memuaskan dan menimbulkan kesan yang menyenangkan. Guru dapat melakukan kegiatan-kegiatan penutupan sebagai berikut:

a) Menarik kesimpulan mengenai materi yang telah dipelajari.

b) Mengajukan beberapa pertanyaan untuk mengukur tingkat pencapaian tujuan dan keefektifan pembelajaran yang telah dilaksanakan.

c) Menyampaikan bahan-bahan pendalaman yang harus dipelajari dan tugas-tugas yang harus dikerjakan sesuai dengan pokok bahasan yang telah dipelajari.

d) Memberikan post test baik secara lisan, tulisan, maupun perbuatan.

2) Memberikan motivasi pada siswa

Sebelum memulai menyampaikan materi pelajaran, guru hendaknya menyemangati dan memotivasi agar bergairah dan tertarik pada pelajaran yang akan disampaikan. Paling sedikit ada empat cara yang dapat dilakukan guru untuk membangkitkan motivasi belajar peserta didik yaitu: kehangatan dan keantusiasan, menimbulkan rasa ingin tahu, mengemukakan ide yang bertentangan, dan memperhatikan minat belajar peserta didik.

${ }^{7}$ Mulyasa, E. 2008. Menjadi Guru Profesional. Menciptakan Pembelajaran Kreatif dan Menyenangkan. Bandung: Remaja Rosdakarya. hlm. 84. 
Sehubungan dengan hal tersebut, motivasi berfungsi:

a) Mendorong siswa untuk berbuat atau merupakan motor penggerak dalam setiap kegiatan yang akan dikerjakan.

b) Menentukan arah kegiatan atau perbuatan yaitu ke arah tujuan yang akan dicapai.

c) Menyeleksi perbuatan yaitu menentukan perbuatan-perbuatan yang harus dikerjakan yang serasi guna mencapai tujuan.

Dengan kata lain, bahwa dengan adanya usaha yang tekun yang didasari adanya motivsi, maka seseorang yang belajar itu akan dapat melakukan prestasi yang baik. Intensitas motivasi siswa akan sangat menentukan tingkat pencapaian prestasi belajarnya.

3) Keterampilan mengadakan variasi

Yang dimaksud variasi ini adalah keterampilan dalam proses mengajar dengan menggunakan beberapa variasi metode, variasi alat/media belajar, dan variasi interaksi. Dalam interaksi edukatif, diharapkan semua yang terlibat di dalamnya berperan sehingga tercipta komunikasi yang baik antara guru dengan siswa. Variasi interaksi sangat tergantung pada variasi metode dan media yang digunakan. Beberapa keuntungan yang dapat diperoleh dengan adanya variasi mengajar misalnya suasana kelas menjadi hidup, perhatian siswa lebih fokus, dan mata pelajaran lebih mudah diterima oleh siswa.

4) Keterampilan menjelaskan

Kegiatan belajar peserta didik dipengaruhi oleh berbagai faktor, seperti motivasi, kematangan, hubungannya dengan guru, dan keterampilan guru dalam berkomunikasi. 
Sehubungan dengan itu, sebagai orang yang bertugas menjelaskan sesuatu, guru harus berusaha membuat sesuatu menjadi jelas bagi peserta didik dan berusaha lebih terampil dalam memecahkan masalah. Guru juga harus mampu menggunakan isyarat non verbal yaitu gerakan-gerakan dari anggota badan untuk memberikan gambaran tentang sesuatu dalam rangka memperjelas maksud atau penjelasan yang diucapkan oleh guru. Demikian banyak gerakangerakan yang dapat dilakukan oleh guru dalam rangka memperjelas maksud atau penjelasan materi pelajaran.

5) Keterampilan membimbing kelompok kecil

Diskusi kelompok kecil merupakan salah satu bentuk kegiatan pembelajaran yang sering digunakan. Hal-hal yang perlu diperhatikan dalam membimbing diskusi adalah sebagai berikut:

a) Memusatkan perhatian peserta didik pada tujuan dan topik diskusi

b) Memperjelas masalah atau urunan pendapat

c) Manganalisis pandangan peserta didik

d) Meningkatkan partisipasi peserta didik

e) Menyebarkan kesempatan berpartisipasi peserta didik

f) Menutup diskusi

Beberapa hal yang perlu dipersiapkan guru agar diskusi kelompok kecil dapat digunakan secara efektif dalam pembelajaran adalah: (a) Topik yang sesuai (b) Pembentukan kelompok secara tepat (c) Pengaturan tempat duduk yang memungkinkan semua peserta didik dapat berpartisipasi secara aktif. ${ }^{8}$

${ }^{8}$ E. Mulyasa, 2008. Ibid., hlm. 91. 
6) Keterampilan mengelola kelas

Pengelolaan kelas secara baik dimaksudkan untuk menciptakan suasana pembelajaran yang lebih kondusif sehingga tujuan pembelajaran dapat tercapai secara efektif dan efisien. ${ }^{9}$ Pengelolaan kelas merupakan keterampilan guru untuk menciptakan iklim pembelajaran yang kondusif dan mengendalikannya jika terjadi gangguan dalam pembelajaran. Menurut Suharsimi pengelolaan kelas berarti suatu usaha yang dilaksanakan penanggung jawab kegiatan belajar mengajar atau membantunya dengan maksud agar tercapai suatu kondisi optimal sehingga terlaksana kegiatan belajar mengajar dapat dicapai seperti yang diharapkan. ${ }^{10}$

Tujuan pengelolaan kelas ialah menyediakan dan menggunakan fasilitas kelas untuk bermacam-macam kegiatan belajar dan mengajar agar mencapai hasil yang baik. Sebagai manajer, guru bertanggung jawab memelihara lingkungan kelasnya agar senantiasa menyenangkan untuk belajar dan mengarahkan serta membimbing proses-proses intelektual dan sosial di dalam kelasnya.

Keterampilan mengelola kelas memiliki komponen yaitu:

a) Penciptaan dan pemeliharaan iklim pembelajaran yang optimal.

b) Keterampilan yang berhubungan dengan pengendalian kondisi belajar yang optimal.

${ }^{9}$ Suwardi, 2007. Op. Cit., hlm. 105.

${ }^{10}$ Arikunto, Suharsimi 1983. Prosedur Penelitian Suatu Pendekatan Praktik. Yogyakarta: Rineka Cipta. hlm. 67. 


\section{Peningkatan Kompetensi Guru}

\section{Guru Sebagai Tenaga Profesional}

Secara umum proses diartikan sebagai suatu pekerjaan yang memerlukan pendidikan lanjut di dalam science dan teknologi yang digunakan sebagai perangkat dasar untuk diimplementasikan dalam berbagai kegiatan yang bermanfaat. ${ }^{11}$ Pengertian guru profesional adalah orang yang memiliki kemampuan dan keahlian khusus dalam bidang keguruan sehingga ia mampu melakukan tugas dan fungsinya sebagai guru dengan kemampuan maksimal. ${ }^{12}$ Dengan kata lain, guru profesional adalah orang yang terdidik dan terlatih dengan baik serta memiliki pengalaman yang kaya di bidangnya.

Jabatan guru hendaklah dipersyaratkan pada keahlian khusus yang harus dipersiapkan melalui pendidikan keahlian atau spesialisasi di bidang pendidikan dan pengajaran. ${ }^{13}$ Guru dituntut adanya kualifikasi kemampuan yang memadai. Secara garis besar ada tiga tingkatan kualifikasi profesional guru sebagai tenaga profesional pendidikan. Yang pertama adalah tingkatan capable personal, maksudnya guru diharapkan memiliki pengetahuan, kecakapan dan keterampilan, serta sikap yang lebih mantap dan memadai sehingga mampu mengelola proses belajar mengajar secara efektif. Tingkat kedua adalah guru sebagai inovator, yakni sebagai tenaga kependidikan yang memiliki komitmen terhadap upaya perubahan dan reformasi. Para guru diharapkan memiliki pengetahuan, kecakapan dan keterampilan serta sikap yang tepat terhadap pembaharuan dan sekaligus merupakan penyebar ide pembaharuan yang efektif. Tingkat ketiga adalah guru sebagai developer,

\footnotetext{
${ }^{11}$ Sardiman, AM, 1990. Op.Cit., hlm. 131.

${ }^{12}$ Usman, 2001. hlm. 15.

${ }^{13}$ Asdiqoh, Siti,. 2012. Etika Profesi Keguruan. Yogyakarta: Trust Media. hlm. 7.
} 
maksudnya guru harus memiliki visi keguruan yang mantap dan luas perspektifnya.

Perlu ditegaskan bahwa selain faktor-faktor pengetahuan, kecakapan, keterampilan, dan tanggap terhadap ide pembaharuan serta wawasan yang lebih luas sesuai dengan keprofesiannya, guru masih memerlukan persyaratan yang bersifat mental, yaitu yang menyebabkan seseorang itu merasa senang karena merasa terpanggil hati nuraninya untuk menjadi seorang guru.

Mengingat tugas dan tanggung jawab guru yang begitu kompleksnya, maka profesi ini menentukan persyaratan, antara lain:

a. Menuntut adanya keterampilan yang berdasarkan konsep dan teori ilmu pengetahuan yang mendalam.

b. Menekankan pada suatu keahlian dalam bidang tertentu sesuai dengan bidang profesinya.

c. Menuntut adanya tingkat pendidikan keguruan yang memadai.

d. Adanya kepekaan terhadap dampak kemasyarakatan dari pekerjaan yang dilaksanakannya.

e. Memungkinkan perkembangan sejalan dengan dinamika kehidupan. ${ }^{14}$

Atas dasar persyaratan tersebut jelaslah jabatan profesional guru harus ditempuh melalui jenjang pendidikan yang khusus mempersiapkan jabatan itu.

\section{Standar Kompetensi Guru}

Kompetensi adalah seperangkat pengetahuan, keterampilan, dan perilaku yang harus dimiliki, dihayati, dan dikuasai oleh guru demi melaksanakan tugas keprofesionalan. Kompetensi merupakan perilaku yang rasional untuk mencapai tujuan yang dipersyaratkan sesuai dengan kondisi

${ }^{14}$ Usman, 2001. hlm. 15. 
yang diharapkan. Adapun kompetensi guru merupakan kemampuan seorang guru dalam menjalankan kewajiban-kewajiban secara bertanggungjawab dan layak.

Berdasarkan pengertian di atas dapat digambarkan bahwa kompetensi merupakan kemampuan dan kewenangan guru dalam melaksanakan profesi keguruannya. Untuk mengetahui kompetensi guru diperlukan ukuran tertentu yang disebut standar kompetensi guru.

Menurut Ditjen Ketenagaan, standar kompetensi guru adalah suatu ukuran yanng ditetapkan atau dipersyaratkan dalam bentuk penguasaan, pengetahuan, dan perilaku perbuatan bagi guru agar berkelayakan untuk menduduki jabatan fungsional sesuai dengan bidang tugas, kualifikasi, dan jenjang pendidikannya. ${ }^{15}$

Undang-undang Sistem Pendidikan Nasional (Sisdiknas 2003 pasal 35 ayat 1), mengemukakan bahwa Standar Nasional Pendidikan terdiri atas standar isi, proses, kompetensi lulusan, tenaga kependidikan, sarana dan prasarana, pengelolaan, pembiayaan, dan penilaian pendidikan yang harus ditingkatkan secara berencana dan berkala. Memahami hal tersebut nampak jelas bahwa guru yang bertugas sebagai pengelola pembelajaran dituntut untuk memiliki standar kompetensi dan profesional. Dirumuskannya standar kompetensi guru bertujuan untuk mendapatkan pedoman dalam pengukuran kinerja guru agar mendapatkan jaminan kualitas guru dalam meningkatkan kualitas proses pembelajaran. ${ }^{16}$ Adanya standar kompetensi guru diharapkan bermanfaat untuk:

${ }^{15}$ Suwardi, 2007. Op. Cit., hlm. 5.

${ }^{16}$ Suwardi, 2007. Ibid., hlm. 5. 
a. Menjadi tolak ukur semua pihak yang berkepentingan di bidang pendidikan.

b. Meningkatkan kinerja guru dalam bentuk kreativitas, inovasi, keterampilan, kemandirian, dan tanggung jawab sesuai dengan jabatan profesinya.

c. Merumuskan bahan untuk pembinaan dan pengembangan kompetensi guru.

d. Merumuskan materi uji kompetensi guru secara bertahap.

Jadi, kompetensi guru dapat dimaknai sebagai kebulatan pengetahuan, keterampilan, dan sikap yang berwujud tindakan cerdas dan penuh tanggung jawab dalam melaksanakan tugas sebagai agen pembelajaran yang ditampilkan melalui unjuk kerja. Dengan demikian, kompetensi yang dimiliki oleh setiap guru akan menunjukkan kualitas guru yang sebenarnya.

Menurut UUGD No. 14/2005 pasal 10 ayat 1 dan PP No. 19/2005 pasal 28 ayat 3, guru wajib memiliki kompetensi yang meliputi kompetensi paedagogik, kepribadian, sosial, dan profesional yang diperoleh melalui pendidikan profesi. Kompetensi paedagogik merupakan kemampuan yang berkaitan dengan pemahaman siswa dan pengelola pembelajaran yang mendidik dan dialogis. Guru yang memiliki kompetensi paedagogik yang baik, ia mampu memahami apa yang dibutuhkan dan diinginkan siswa dalam proses pembelajaran, juga mempunyai banyak variasi mengajar. Guru berkewajiban untuk mengembangkan kompetensi paedagogik yang dimilikinya.

Kompetensi kepribadian merupakan kemampuan profesional yang mencerminkan kepribadian yang mantap, stabil, dewasa, arif, dan 
berwibawa, menjadi teladan bagi siswa yang berakhlak mulia. ${ }^{17}$ Guru yang memiliki kompetensi kepribadian yang kurang baik akan mempengaruhi cara mengajar mereka sehingga berdampak pada peningkatan kualitas pembelajaran.

Kompetensi sosial berkaitan dengan kemampuan pendidik sebagai bagian dari masyarakat untuk berkomunikasi dan bergaul secara efektif dengan siswa, sesama pendidik, orang tua/wali siswa, dan masyarakat sekitar. Kompetensi sosial menurut guru selalu berpenampilan menarik, berempati, suka berkerja sama, suka menolong, dan memiliki kemampuan yang baik dalam berkomunikasi. Kemampuan bergaul dan berkomunikasi bagi guru sangat penting karena hubungan yang akrab antara guru dengan siswa menyebabkan siswa tidak takut atau ragu mengungkapkan permasalahan belajarnya.

Kemampuan profesional menggambarkan tentang kemampuan yang harus dimiliki oleh seorang guru yang mengampu jabatan guru. Kompetensi ini merupakan kemampuan yang berkaitan dengan penguasaan materi pembelajaran. Kompetensi profesional menuntut setiap guru untuk menguasai materi yang akan diajarkan termasuk langkah-langkah yang perlu diambil guru dalam memperdalam pengusaan bidang studi yang diampunya.

Standarisasi kompetensi guru adalah suatu ukuran yang ditetapkan bagi seorang guru dalam menguasai seperangkat kemampuan agar layak menduduki salah satu jabatan fungsional guru sesuai bidang tugas dan jenjang pendidikannya. Manfaat dari hasil standarisasi antara lain (1) dapat memberikan informasi tentang peta kemampuan guru yang layak dan tidak layak, baik secara individual maupun kelompok, (2) peningkatan 
kompetensi, peningkatan kualifikasi, (3) peningkatan dan pengembangan karir dan profesi guru.

\section{Pemberdayaan Guru Melalui Standar dan Sertifikasi}

Dalam rangka peningkatan kemampuan profesional guru perlu dilakukan sertifikasi dan diuji kompetensi secara berkala agar kinerjanya terus meningkat dan tetap memenuhi syarat profesional. Karena pada hakikatnya standar kompetensi dan sertifikasi guru adalah untuk mendapatkan guru yang baik dan profesional. Sertifikat kompetensi diperoleh dari penyelenggara pendidikan dan lembaga pelatihan setelah lulus uji kompetensi. Uji kompetensi guru dapat dilakukan secara nasional, regional, maupun lokal. Uji kompetensi guru, baik secara teoritis maupun praktis memiliki manfaat dalam rangka meningkatkan kualitas pendidikan melalui peningkatan kualitas guru.

Berdasarkan hasil uji kompetensi dapat diketahui kemampuan para guru. Aspek mana yang perlu ditingkatkan dan siapa yang perlu mendapatkan pembinaan. Dengan demikian, uji kompetensi guru merupakan sesuatu yang penting untuk dilakukan terhadap setiap guru dan calon guru untuk mempersiapkan guru yang kreatif, profesional, dan menyenangkan.

\section{DAFTAR PUSTAKA}

Arikunto, Suharsimi 1983. Prosedur Penelitian Suatu Pendekatan Praktik. Yogyakarta: Rineka Cipta.

Asdiqoh, Siti,. 2012. Etika Profesi Keguruan. Yogyakarta: Trust Media.

Ibnu Rusn, Abidin, ,. 1998. Pemikiran Al-Ghazali Tentang Pendidikan. Yogyakarta: Pustaka Pelajar.

Mulyasa, E. 2007. Standar Kompetensi dan Sertifikasi Guru. Bandung: Remaja Rosdakarya. 
Mulyasa, E. 2008. Menjadi Guru Profesional. Menciptakan Pembelajaran Kreatif dan Menyenangkan. Bandung: Remaja Rosdakarya.

Sardiman A.M., 1990. Interaksi dan Motivasi Belajar Mengajar. Jakarta: Rajawali.

Suwardi. 2007. Manajemen Pembelajaran, Mencipta Guru Kreatif dan Berkompetensi. Salatiga: STAIN Salatiga Press.

Uzer Usman Moh.,. 2001. Menjadi Guru Profesional. Bandung: Remaja Rosdakarya. 